\title{
Phenotypic variability in chorea-acanthocytosis associated with novel VPS13A mutations
}

Valter Niemelä, MD, PhD, Ammar Salih, MD, Daniela Solea, MD, Björn Lindvall, MD, Jan Weinberg, MD, PhD, Gabriel Miltenberger, MD, Tobias Granberg, MD, PhD, Aikaterini Tzovla, MD, Love Nordin, PhD,

Torsten Danfors, MD, PhD, Irina Savitcheva, MD, PhD, Niklas Dahl, MD, PhD, and Martin Paucar, MD, PhD

Neurol Genet 2020;6:e426. doi:10.1212/NXG.0000000000000426

\section{Abstract}

\section{Objective}

To perform a comprehensive characterization of a cohort of patients with choreaacanthocytosis (ChAc) in Sweden.

\section{Methods}

Clinical assessments, targeted genetic studies, neuroimaging with MRI, $\left[{ }^{18} \mathrm{~F}\right]$-fluorodeoxyglucose (FDG) PET, and dopamine transporter with ${ }^{123}$ I FP-CIT (DaTscan) SPECT. One patient underwent magnetic resonance spectroscopy (MRS).

\section{Results}

Four patients living in Sweden but with different ethnical backgrounds were included. Their clinical features were variable. Biallelic VPS13A mutations were confirmed in all patients, including 3 novel mutations. All tested patients had either low or absent chorein levels. One patient had progressive caudate atrophy. Investigation using FDG-PET revealed severe bilateral striatal hypometabolism, and DaTscan SPECT displayed presynaptic dopaminergic deficiency in 3 patients. MRS demonstrated reduced $\mathrm{N}$-acetylaspartate/creatine $(\mathrm{Cr})$ ratio and mild elevation of both choline/ $\mathrm{Cr}$ and combined glutamate and glutamine/ $\mathrm{Cr}$ in the striatum in 1 case. One patient died during sleep, and another was treated with deep brain stimulation, which transiently attenuated feeding dystonia but not his gait disorder or chorea.

\section{Conclusions}

Larger longitudinal neuroimaging studies with different modalities, particularly MRS, are needed to determine their potential role as biomarkers for ChAc.

\author{
Correspondence \\ Dr. Paucar \\ martin.paucar-arce@sll.se
}

MORE ONLINE

- Video 


\section{Glossary}

$\mathbf{B G}=$ basal ganglia; $\mathbf{C C} / \mathbf{I T}=$ intercaudate distance to inner table width ratio; $\mathbf{C h A c}=$ chorea-acanthocytosis; $\mathbf{C h o}=$ choline; $\mathbf{C r}=$ creatine; $\mathbf{D B S}=$ deep brain stimulation; FDG = fluorodeoxyglucose; $\mathbf{F H} / \mathbf{C C}=$ frontal horn width to intercaudate distance ratio; Glx = glutamine; HD = Huntington disease; MLS = McLeod syndrome; MRS = magnetic resonance spectroscopy; NAA $=\mathrm{N}$-acetylaspartate.

Chorea-acanthocytosis (ChAc) and McLeod syndrome (MLS) are the main forms of neuroacanthocytosis disorders, characterized by progressive and incurable hyperkinesias, neuromuscular abnormalities, and a reduced life span. However, epilepsy is common in ChAc, whereas dilated cardiomyopathy is a distinctive feature in $2 / 3$ of patients with MLS. ${ }^{1}$ Caudate atrophy is progressive in MLS but has not been described in $\mathrm{ChAc}^{2}$ caused by biallelic mutations in the vacuolar protein sorting 13 homolog A (VPS13A) gene, encoding chorein. ${ }^{1}$ Currently, almost 1,000 cases with ChAc have been reported in various populations. Here, we characterize 4 patients affected by ChAc and 3 new truncating mutations in VPS13A.

\section{Methods}

The patients ( 2 males and 2 females) were evaluated at 4 different centers in Sweden (table 1). Patients or their next-of-kin provided oral and written consent for this study, approved by the Regional Ethics Committee of Stockholm. Patients underwent clinical evaluation of motor features with Unified Huntington's Disease Rating Scale, cognitive screening with Montreal Cognitive Assessment, psychometric testing, laboratory tests, blood smears, and/or ancillary tests such as neurophysiologic tests and/ or muscle biopsy. Analysis of the VPS13A gene was performed following exclusion of a trinucleotide expansion in the huntingtin (HTT) gene. The ClinVar database (ncbi.nlm.nih.gov/clinvar) was used to assess novelty of VPS13A mutations, and MutationTaster (mutationtaster.org) was used to predict the effects of mutations. Western blot for chorein in blood was performed in patients 1, 3, and 4 (Western blot analysis for chorein were performed with the financial support of the Advocacy for Neuroacanthocytosis Patients in the laboratories of Drs. Bettina Schmid (Biochemistry/DZNE) and Adrian Danek (Neurology) at Ludwig-Maximilians-Universität Munich, Germany). Neuroimaging included MRI, $\left[{ }^{18} \mathrm{~F}\right]$-fluorodeoxyglucose (FDG)PET/ $\mathrm{CT}$, and assessment of presynaptic dopamine transporter with ${ }^{123}$ I-labeled $\quad \mathrm{N}$-(3-fluoropropyl)-2 $\beta$-carbomethoxy-3 $\beta$-(4-iodophenyl)nortropane (FP-CIT) DaTscan SPECT. The parameters evaluated in Huntington disease (HD), frontal horn width to intercaudate distance ratio $(\mathrm{FH} / \mathrm{CC})$ and intercaudate distance to inner table width ratio (CC/IT), were measured. Magnetic resonance spectroscopy (MRS) was performed only in patient 1 . Briefly, the concentrations of N-acetylaspartate (NAA), choline (Cho), combined glutamate and glutamine $(\mathrm{Glx})$, creatine $(\mathrm{Cr})$, and phosphocreatine were measured in the putamen and globus pallidus. These results were compared with normative data from 20 healthy controls (supplementary material, links.lww.com/ NXG/A255).

\section{Data availability}

Data not provided in this article are available in a trusted repository (doi.org/10.5061/dryad.7h44j0zr9).

\section{Results}

\section{Phenotype and genetics}

The clinical features and mutations are summarized in table 1. Briefly, the mean age at onset was 34 (range 30-38) years, and the disease duration was 9.5 (range 2-17) years. All patients presented with cognitive decline of variable degree, and laboratory investigations revealed elevated creatine kinase levels and acanthocytes in blood smears. Feeding dystonia was prominent in patient 1 and therefore treated with botulinum injections in the tongue base $\mathrm{e}^{3}$ and later with bilateral deep brain stimulation (DBS) of the internal globus pallidus that resulted in a transient attenuation of feeding dystonia. Western blot analysis revealed absent chorein in patient 1 and low levels in patients 3 and 4. Chorea, dystonia, and vocalizations were initial features in patients 1 and 3, and their severe gait disorder was overcome when walking backward. Both patients were compound heterozygous for VPS13A mutations. In patient 2 , seizures were the first symptom, followed by hyperkinesias and myopathy at later stages. Genetic investigation revealed homozygosity for a VPS13A mutation. The patient died during sleep at age 42 years despite good seizure control, and autopsy revealed incidental sarcoidosis affecting the heart. Patient 3 was diagnosed with tourettism during adolescence, followed by progressive hyperkinesias and a gait disorder that became evident at age 30 years. Symptoms progressed with generalized dystonia, predominantly of the torso, and marked blepharospasm. Genetic investigation revealed compound heterozygosity for VPS13A mutations. A younger sibling of patient 3 , not investigated for VPS13A mutations, had seizures without motor abnormalities and died during sleep. Patient 4 had chorea and depression; her genetic investigation revealed homozygosity for a VPS13A mutation. Three of the 6 VPS13A mutations were new and pathogenic (table 1 and supplementary material, links.lww. com/NXG/A255). The course of disease for patient 1 is shown in video 1 ; patients 3 and 4 declined video recordings of their examination.

\section{Neuroimaging}

MRI displayed variable degrees of striatal atrophy in all patients that was progressive in patient 3. Patient 1 had FH/ $\mathrm{CC}=1.6$ (normal range: $2.2-2.6$ ) and $\mathrm{CC} / \mathrm{IT}=0.18$ (normal range: $0.09-0.12)$ at age 37 years, with unchanged ratios 5 
Table 1 Acanthocytes were present in all 3 patients, and chorein was absent in blood in patient 1

\begin{tabular}{|c|c|c|c|c|c|}
\hline \multirow{3}{*}{$\begin{array}{l}\text { Features and } \\
\text { genetics }\end{array}$} & \multirow{2}{*}{$\begin{array}{l}\text { Case no. } \\
\text { Ethnicity }\end{array}$} & \multirow{2}{*}{1} & \multirow{2}{*}{2} & \multirow{2}{*}{3} & \multirow{2}{*}{4} \\
\hline & & & & & \\
\hline & Sex & M & $\mathbf{F}$ & M & $\mathbf{F}$ \\
\hline \multirow[t]{3}{*}{ Clinical course } & Age at onset & 33 & 36 & 30 & 37 \\
\hline & Current age or age at death ${ }^{b}$ & 46 & $42^{b}$ & $47^{c}$ & 40 \\
\hline & Symptom at onset & $\begin{array}{l}\text { Personality change and } \\
\text { chorea }\end{array}$ & Epilepsy & $\begin{array}{l}\text { Gait disorder, facial } \\
\text { chorea, and } \\
\text { vocalizations }\end{array}$ & $\begin{array}{l}\text { Chorea and } \\
\text { fatigue }\end{array}$ \\
\hline \multirow[t]{4}{*}{ Motor features } & Predominant motor symptoms & $\begin{array}{l}\text { Chorea, dystonia, } \\
\text { postural instability, and } \\
\text { bradykinesia }\end{array}$ & $\begin{array}{l}\text { Chorea, postural } \\
\text { instability, oral dystonia, } \\
\text { and vocal tics }\end{array}$ & $\begin{array}{l}\text { Generalized dystonia } \\
\text { and severe } \\
\text { blepharospasm }\end{array}$ & $\begin{array}{l}\text { Chorea, } \\
\text { including oral } \\
\text { tics }\end{array}$ \\
\hline & Chorea & + & + & + & + \\
\hline & UHDRS (latest) & 43 & NA & 55 & 25 \\
\hline & Feeding dystonia & + & - & $(+)$ & - \\
\hline \multirow{3}{*}{$\begin{array}{l}\text { Cognitive and } \\
\text { behavioral } \\
\text { function }\end{array}$} & Cognitive impairment & + & + & $(+)$ & + \\
\hline & MoCA & 28 & NA & NA & 13 \\
\hline & Psychiatric symptoms & + Frontal disinhibition & - & + Tourettism & + Depression \\
\hline \multirow{4}{*}{$\begin{array}{l}\text { Neuromuscular } \\
\text { assessment }\end{array}$} & Muscle weakness/atrophy & + & + & ND & - \\
\hline & Reduced deep tendon reflexes & + & + & + & + \\
\hline & $\begin{array}{l}\text { Neuropathy (confirmed with } \\
\text { ENeG) }\end{array}$ & - & NA & - & - \\
\hline & Myopathy & + & + & NA & - \\
\hline $\begin{array}{l}\text { Other } \\
\text { neurologic } \\
\text { features }\end{array}$ & Epilepsy & - & + & - & - \\
\hline \multirow[t]{4}{*}{$\begin{array}{l}\text { Laboratory } \\
\text { testing }\end{array}$} & $\begin{array}{l}\text { CK (x upper reference value) } \\
\text { (Ref. men } 0.8-6.7 \text { and women } \\
0.6-3.5 \mu \mathrm{kat} / \mathrm{L} \text { ) }\end{array}$ & $+(15 x)$ & $+(19 x)$ & $+(4 x)$ & $+(3 x)$ \\
\hline & Elevated AST or ALT & + & + & - & - \\
\hline & Acanthocytes & + & + & + & + \\
\hline & Chorein & Absent & NA & Low & Low \\
\hline \multirow[t]{3}{*}{ Imaging studies } & MRI caudate atrophy & + & + & + Progressive & + \\
\hline & $\begin{array}{l}\text { Reduced striatal uptake } \\
\text { (DaTscan) }\end{array}$ & + & NA & + & + \\
\hline & $\begin{array}{l}\text { Striatal hypometabolism (FDG- } \\
\text { PET) }\end{array}$ & + & NA & + & + \\
\hline Genetics & Mutations in VPS13A & $\begin{array}{l}\text { c.266dupT; exon 51-59 } \\
\text { del (p.lle90Tyrfs*; p?) }\end{array}$ & $\begin{array}{l}\text { Homozygous c.4162_ } \\
4166 \text { delins C } \\
\text { (p.Leu1388Glu-fsx6) }\end{array}$ & $\begin{array}{l}\text { c. } 2428-2 A>G ; \\
\text { c. } 1595+4 \text { _ } \\
\text { 1595+7delAGTA ( } p ? \\
\text { p?) }\end{array}$ & $\begin{array}{l}\text { Homozygous } \\
\text { c.7867C }>\mathrm{T} \\
\text { (p.Arg2623X) }\end{array}$ \\
\hline
\end{tabular}

Abbreviations: + = present: - = absent; $(+)=$ mild feature; ALT = alanine transaminase; $A S T=$ aspartate aminotransferase; $C K=$ creatine kinase; FDG = fluorodeoxyglucose; MoCA = Montreal Cognitive Assessment; NA = no assessed; ND = no determined; UHDRS = Unified Huntington's Disease Rating Scale. All patients also had areflexia and hyperCKemia. Mutations for patients 2 and 3 are new.

a Treated with bilateral deep brain stimulation of the internal globus pallidus.

${ }^{\mathrm{b}}$ Sudden unexpected death in epilepsy (SUDEP). Age at death was 42.

CA younger brother to patient 3 had epilepsy at age 24 years and died during sleep at age 28 years; however, he did not show obvious movement abnormalities. 
years later. MRS for patient 1 demonstrated a mild reduction of NAA/Cr ratio and mild elevation of Cho/Cr and Glx/Cr in the striatum (table e-1 and figure e-1, links.lww.com/NXG/ A255). Patient 3 had FH/CC $=1.5$ and $\mathrm{CC} / \mathrm{IT}=0.20$ at age 39 years. Six years later, the FH/CC was 1.2 and CC/IT 0.26 , indicating progressive caudate atrophy (figure e-4). Patients 2 and 4 had iron deposition in the globus pallidus. In patients 1 , 3 , and 4 , we observed profound reduction of glucose metabolism in the dorsal striatum (caudate nucleus and putamen) and reduced dopamine transporter binding (figure 1 and supplementary document). Patients 1 and 3 also had an increased glucose metabolism in the thalamus, whereas patient 4 had a normal thalamic metabolism. An extended description on the clinical course and neuroimaging findings are found in the supplementary files (figures e-1 to e-5).

\section{Discussion}

Here, we add to the number of VPS13A mutations associated with variable phenotypic expression in 4 cases of ChAc. Similar to HD, structural neuroimaging for ChAc demonstrated both caudate atrophy with dilatation of the anterior horns and variable cortical atrophy. ${ }^{1,4}$ Other MRI findings include increased $\mathrm{T} 2$-weighted signal in the caudate and putamen and hippocampal sclerosis and atrophy, ${ }^{1}$ in contrast to some patients with ChAc with normal findings in the basal ganglia (BG). ${ }^{5}$ In addition, iron accumulation in the BG in patient 2 is in line with previous findings in $\mathrm{ChAc}^{1}$. Caudate atrophy is progressive in MLS, ${ }^{2}$ but this is, to our knowledge, the first report on progressive caudate atrophy in ChAc.

Consistent with previous studies on ChAc, we identified severe hypometabolism in the BG, loss of dopaminergic nigrostriatal projections, and dopamine transporter binding sites in all assessed patients. ${ }^{6-9}$ Importantly, hypometabolism in the BG is not specific for ChAc, as it occurs also in MLS and HD. Furthermore, patients 1 and 3 had increased metabolism in the thalamus. Whereas thalamic hypermetabolism has been reported in patients with blepharospasm, ${ }^{10}$ we noted that only patient 3 has generalized dystonia and blepharospasm. The only previous MRS study in genetically confirmed ChAc demonstrated decreased NAA/Cr ratio in the atrophic striatum of 2 brothers. ${ }^{8}$ This abnormality reflects neuronal loss and gliosis. In contrast, the myo-inositol/Cr ratio was increased in this part of the BG. MRS abnormalities have previously been described in cortical areas of 5 patients with MLS, but abnormalities in the striatum were not determined. ${ }^{11}$ In HD, MRS abnormalities are widespread and depend on disease stage. Our results showing reduced NAA, reflecting neuronal loss and gliosis, are in line with previous observations. The elevations of Cho, reflecting increased cellular membrane turnover and glutamate/Glx, suggest a possible role of glutamate excitotoxicity in ChA as a potential biomarker in the pathophysiology of ChAc.

A common clinical feature is the progression into bradykinesia, observed in 2 of 4 patients. The low binding of DaTscan to dopamine transporter in the striatum is a reasonable correlate to parkinsonism in patients 1 and 3; neuronal loss has been described in patients with $\mathrm{ChAc}$ with parkinsonism. ${ }^{1}$ On the other hand, reduced binding in patient 4 is likely a premonitory sign of hypokinesia and no a side effect of neuroleptic since DaTscan is a presynaptic tracer. To date, there are only 5 reports on genetically confirmed ChAc in Scandinavia. ${ }^{3, \mathrm{e} 2, \mathrm{e} 3, \mathrm{e} 8, \mathrm{e} 9}$ All 6 mutations reported herein are truncating, and 3 of them are novel. This is consistent with previously reported VSP13A gene mutations, of which the majority predict a complete or partial loss of protein function. ${ }^{\mathrm{e} 3}$ Low or absent chorein levels in 3 of our patients strengthen the notion that the VPS13A variants are indeed pathogenic. The reasons for the wide clinical variability in ChAc remain elusive. ${ }^{1}$ Patient 3 presented with tourettism during adolescence and was diagnosed with $\mathrm{ChAc}$ at age 30 years, followed by a disease course spanning 17 years. This is remarkable considering that the mean disease duration in ChAc is 11 years. ${ }^{\text {e4 }}$ Furthermore, sudden unexpected death in epilepsy (SUDEP) appears to be common in $\mathrm{ChAc}$ and was recently reported in 6 of 52 patients. ${ }^{\mathrm{e} 4}$ Patient 2 died during sleep at age 42 years, raising the

Figure 1. Neuroimaging findings in chorea-achantocytosis

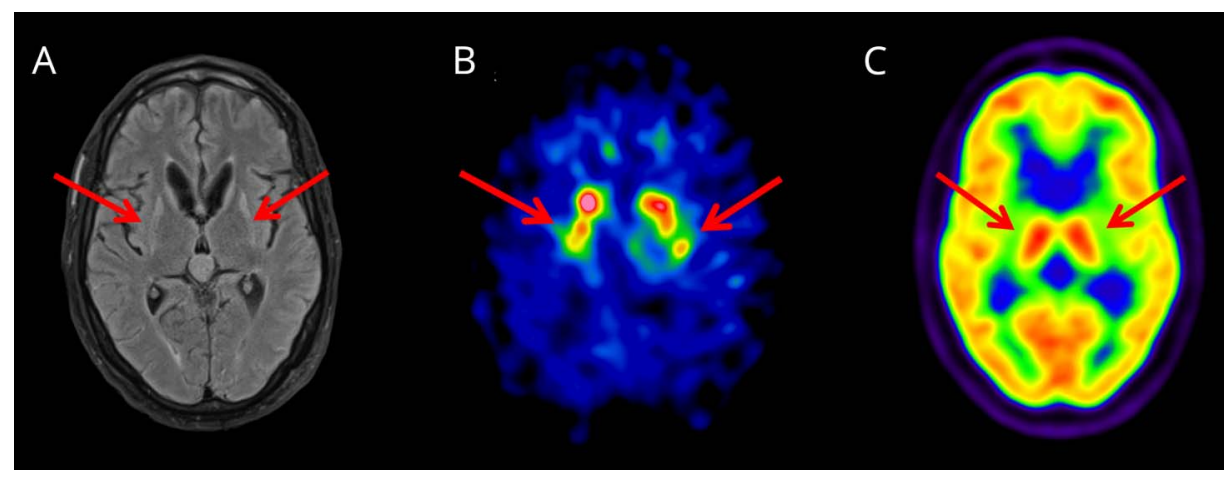

Axial T2-weighted FLAIR MRI of patient 3 (at age 46 years) shows a pronounced atrophy of the caudate nuclei and putamina and increased signal intensity from the putamina (arrows) (A) DaTscan SPECT and fluorodeoxyglucose PET in the same patient at age 43 years demonstrate very low DAT density in both putamen ( $B$, arrows) respectively severe hypometabolism in the striata (C, arrows). DAT = dopamine transporter; FLAIR = fluid-attenuated inversion recovery. 
suspicion of SUDEP. However, it cannot be excluded that the presence of sarcoidosis in her heart could have predisposed to a lethal arrhythmia.

Although our report brings additional information to the genetic and clinical variability in $\mathrm{ChAc}$, the retrospective nature of our study precluded volumetric MRI analyses. Finally, our study calls for further longitudinal neuroimaging studies using different modalities to assess their potential role as biomarkers in ChAc.

\section{Acknowledgment}

The authors are truly grateful to the patients and their next-ofkin for consenting for this report. The authors also thank psychologist Å. Bergendal and Dr. G. Schechtmann for cognitive evaluations respectively performing DBS surgery in patient 1. M. Paucar's research is supported by Region Stockholm.

\section{Study funding}

M. Paucar is supported by Region Stockholm and N. Dahl by the Swedish Research Council (2015-02424).

\section{Disclosure}

V. Niemelä, A. Salih, D. Solea, B. Lindvall, J. Weinberg, G. Miltenberger, T. Granberg, A. Tzovla, L. Nordin, T. Danfors, I. Savitcheva, N. Dahl, and M. Paucar report no disclosures. Go to Neurology.org/NG for full disclosure.

\section{Publication history}

Received by Neurology: Genetics October 16, 2019. Accepted in final form March 27, 2020.

\section{Appendix Authors}

\begin{tabular}{|c|c|c|}
\hline Name & Location & Contribution \\
\hline $\begin{array}{l}\text { Valter } \\
\text { Niemelä, MD, } \\
\text { PhD }\end{array}$ & $\begin{array}{l}\text { Uppsala University } \\
\text { Hospital }\end{array}$ & $\begin{array}{l}\text { Drafting and revising the } \\
\text { manuscript; study } \\
\text { coordination; and analysis } \\
\text { and interpretation of data }\end{array}$ \\
\hline $\begin{array}{l}\text { Ammar Salih, } \\
\text { MD }\end{array}$ & Västerås Hospital & $\begin{array}{l}\text { Drafting and revising the } \\
\text { manuscript; patient care; } \\
\text { and analysis and } \\
\text { interpretation of data }\end{array}$ \\
\hline $\begin{array}{l}\text { Daniela Solea, } \\
\text { MD }\end{array}$ & Gävle Hospital & $\begin{array}{l}\text { Drafting and revising the } \\
\text { manuscript; patient care; } \\
\text { and analysis and } \\
\text { interpretation of data }\end{array}$ \\
\hline $\begin{array}{l}\text { Björn } \\
\text { Lindvall, MD }\end{array}$ & $\begin{array}{l}\text { University Hospital in } \\
\text { Örebro }\end{array}$ & $\begin{array}{l}\text { Drafting and revising the } \\
\text { manuscript; patient care; } \\
\text { and analysis and } \\
\text { interpretation of data }\end{array}$ \\
\hline $\begin{array}{l}\text { Jan Weinberg, } \\
\text { MD, PhD }\end{array}$ & $\begin{array}{l}\text { Karolinska University } \\
\text { Hospital }\end{array}$ & $\begin{array}{l}\text { Drafting and revising the } \\
\text { manuscript; patient care; } \\
\text { and analysis and } \\
\text { interpretation of data }\end{array}$ \\
\hline
\end{tabular}

Appendix (continued)

\begin{tabular}{|c|c|c|}
\hline Name & Location & Contribution \\
\hline $\begin{array}{l}\text { Gabriel } \\
\text { Miltenberger, } \\
\text { MD }\end{array}$ & $\begin{array}{l}\text { Department of } \\
\text { Neurology, Ludwig- } \\
\text { Maximilians-Universität } \\
\text { München }\end{array}$ & $\begin{array}{l}\text { Western blot analyses and } \\
\text { revising the manuscript }\end{array}$ \\
\hline $\begin{array}{l}\text { Tobias } \\
\text { Granberg, } \\
\text { MD, PhD }\end{array}$ & $\begin{array}{l}\text { Karolinska University } \\
\text { Hospital and Karolinska } \\
\text { Institutet }\end{array}$ & $\begin{array}{l}\text { Drafting and revising the } \\
\text { manuscript and analysis } \\
\text { and interpretation of } \\
\text { neuroimaging data }\end{array}$ \\
\hline $\begin{array}{l}\text { Aikaterini } \\
\text { Tzovla, MD }\end{array}$ & $\begin{array}{l}\text { Karolinska University } \\
\text { Hospital }\end{array}$ & $\begin{array}{l}\text { Drafting and revising the } \\
\text { manuscript and analysis } \\
\text { and interpretation of } \\
\text { neuroimaging data }\end{array}$ \\
\hline $\begin{array}{l}\text { Love Nordin, } \\
\text { PhD }\end{array}$ & $\begin{array}{l}\text { Karolinska University } \\
\text { Hospital and Karolinska } \\
\text { Institutet }\end{array}$ & $\begin{array}{l}\text { Drafting and revising the } \\
\text { manuscript and analysis } \\
\text { and interpretation of MRS } \\
\text { data }\end{array}$ \\
\hline $\begin{array}{l}\text { Torsten } \\
\text { Danfors, MD, } \\
\text { PhD }\end{array}$ & $\begin{array}{l}\text { Uppsala University } \\
\text { Hospital }\end{array}$ & $\begin{array}{l}\text { Drafting and revising the } \\
\text { manuscript and analysis } \\
\text { and interpretation of PET } \\
\text { data }\end{array}$ \\
\hline $\begin{array}{l}\text { Irina } \\
\text { Savitcheva, } \\
\text { MD, PhD }\end{array}$ & $\begin{array}{l}\text { Karolinska University } \\
\text { Hospital }\end{array}$ & $\begin{array}{l}\text { Drafting and revising the } \\
\text { manuscript and analysis } \\
\text { and interpretation of PET } \\
\text { data }\end{array}$ \\
\hline $\begin{array}{l}\text { Niklas Dahl, } \\
\text { MD, PhD }\end{array}$ & $\begin{array}{l}\text { Uppsala University } \\
\text { Hospital }\end{array}$ & $\begin{array}{l}\text { Revising the manuscript; } \\
\text { study concept and design; } \\
\text { analysis and interpretation } \\
\text { of data; and study } \\
\text { supervision and } \\
\text { coordination }\end{array}$ \\
\hline $\begin{array}{l}\text { Martin } \\
\text { Paucar, MD, } \\
\text { PhD }\end{array}$ & $\begin{array}{l}\text { Karolinska University } \\
\text { Hospital and Karolinska } \\
\text { Institutet }\end{array}$ & $\begin{array}{l}\text { Revising the manuscript; } \\
\text { study concept and design; } \\
\text { analysis and interpretation } \\
\text { of data; and study } \\
\text { supervision and } \\
\text { coordination }\end{array}$ \\
\hline
\end{tabular}

\section{References}

1. Velayos Baeza A, Dobson-Stone C, Rampoldi L, et al. Chorea-acanthocytosis. 2002. In: Adam MP, Ardinger HH, Pagon RA, et al, editors. GeneReviews ${ }^{\circledast}$ [Internet] Seattle, WA: University of Washington, Seattle; 1993-2019.

2. Valko PO, Hänggi J, Meyer M, Jung HH. Evolution of striatal degeneration in McLeod syndrome. Eur J Neurol 2010;17:612-618.

3. Paucar M, Lindestad PÅ, Walker RH, et al. Teaching video NeuroImages: feeding dystonia in chorea-acanthocytosis. Neurology 2015;85:e143-e144.

4. Walterfang M, Looi JC, Styner M, et al. Shape alterations in the striatum in choreaacanthocytosis. Psychiatry Res 2011;192:29-36.

5. Estévez-Fraga C, López-Sendón Moreno JL, Martínez-Castrillo JC; Spanish Collaborative Neuroacanthocytosis Group. Phenomenology and disease progression of chorea-acanthocytosis patients in Spain. Parkinsonism Relat Disord 2018;49:17-21.

6. Brooks DJ, Ibanez V, Playford ED, et al. Presynaptic and postsynaptic striatal dopaminergic function in neuroacanthocytosis: a positron emission tomographic study. Ann Neurol 1991;30:166-171.

7. Müller-Vahl KR, Berding G, Emrich HM, et al. Chorea-acanthocytosis in monozygotic twins: clinical findings and neuropathological changes as detected by diffusion tensor imaging, FDG-PET and (123)I-beta-CIT-SPECT. J Neurol 2007;254:1081-1088.

8. Ismailogullari S, Caglayan AO, Bader B, et al. Magnetic resonance spectroscopy in two siblings with chorea-acanthocytosis. Mov Disord 2010;25:2894-2897.

9. Cui R, You H, Niu N, et al. FDG PET brain scan demonstrated glucose hypometabolism of bilateral caudate nuclei and putamina in a patient with chorea-acanthocytosis. Clin Nucl Med 2015;40:979-980.

10. Suzuki Y, Mizoguchi S, Kiyosawa M, et al. Glucose hypermetabolism in the thalamus of patients with essential blepharospasm. J Neurol 2007;254:890-896.

11. Dydak U, Mueller S, Sándor PS, Meier D, Boesiger P, Jung HH. Cerebral metabolic alterations in McLeod syndrome. Eur Neurol 2006;56:17-23. 


\section{Neurology

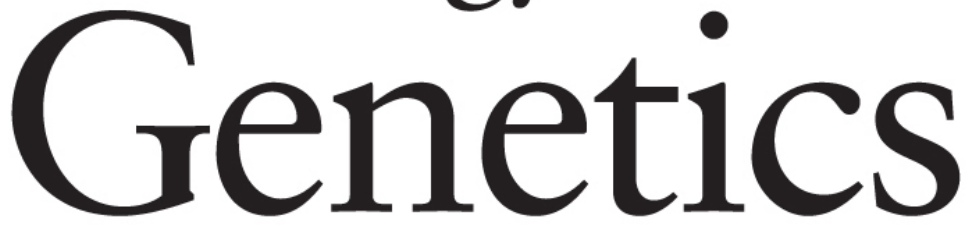

\section{Phenotypic variability in chorea-acanthocytosis associated with novel VPS13A mutations}

Valter Niemelä, Ammar Salih, Daniela Solea, et al.

Neurol Genet 2020;6;

DOI 10.1212/NXG.0000000000000426

This information is current as of April 28, 2020

\section{Updated Information \& Services}

References

Subspecialty Collections

Permissions \& Licensing

Reprints including high resolution figures, can be found at: http://ng.neurology.org/content/6/3/e426.full.html

This article cites 10 articles, 0 of which you can access for free at: http://ng.neurology.org/content/6/3/e426.full.html\#\#ref-list-1

This article, along with others on similar topics, appears in the following collection(s):

All Genetics

http://ng.neurology.org//cgi/collection/all_genetics All global neurology

http://ng.neurology.org//cgi/collection/all_global_neurology Chorea

http://ng.neurology.org//cgi/collection/chorea

Information about reproducing this article in parts (figures,tables) or in its entirety can be found online at:

http://ng.neurology.org/misc/about.xhtml\#permissions

Information about ordering reprints can be found online: http://ng.neurology.org/misc/addir.xhtml\#reprintsus

Neurol Genet is an official journal of the American Academy of Neurology. Published since April 2015, it is an open-access, online-only, continuous publication journal. Copyright Copyright $\odot 2020$ The Author(s). Published by Wolters Kluwer Health, Inc. on behalf of the American Academy of Neurology.. All rights reserved. Online ISSN: 2376-7839.

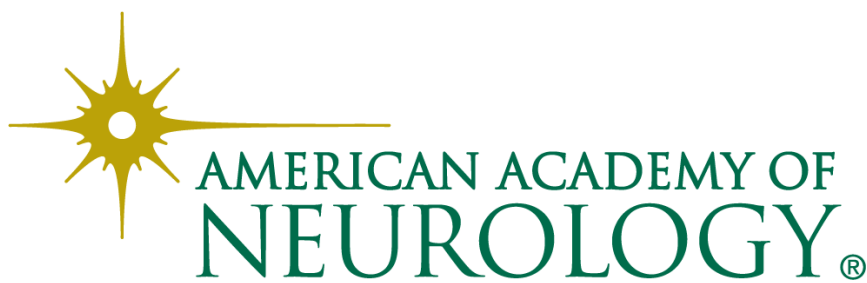

